甜茶抽出物のアリルメチルスルフィド に対する消臭効果

清水和正 ${ }^{8}$, 前田裕一, 大澤謙二, 志村 進

(株)ロッテ中央研究所

Deodorizing Effect of Rubus suavissimus Extract against Allyl Methyl Sulfide

Katsumasa Shimizu ${ }^{\S}$, Yuichi Maeda,

Kenji Osawa and Susumu Shimura

Lotte Central Laboratory Co., Ltd., 3-1-1, Numakage, Minami-ku, Saitama-shi, Saitama 336-8601

The deodorizing activity of various kinds of plant extracts on allylmethylsulfide (AMS) in the breath after eating garlic was measured by gas chromatography. Among these extracts, water extract of Rubus suavissimus (RSW) showed the highest deodorizing activity against AMS. The active components of $R$. suavissimus were considered to be a mixture of polyphenolic compounds, because of positive correlation with deodorizing activity and polyphenol content in RSW. As a result of the separation of RSW in guidance with deodorizing activity by column chromatography of Diaion HP20 and Sephadex LH-20, the fraction RSW-24 possessed the highest deodorizing effect. And allylmethylsulfoxide was detected in the reaction mixture of AMS and $\mathrm{RSW}-24$. The deodorizing activity of RSW-24 was disappeared under anaerobic conditions. It was suggested that the reaction mechanism of RSW against AMS was the oxidative reaction by polyphenolic compounds.

(Received Aug. 6, 2003 ; Accepted Jan. 27, 2004)

近年，エチケット意識の高まりとともに，口臭を気にか ける人が増えてきている．食事に由来する外因性の口臭の 中では, ニンニクを掑取した際に現れるロ臭は非常に強 く，これを嫌う人が多いことは一般に良く知られている。 ニンニク摂取後の呼気成分についての最近の研究によ り，摂取直後から発生するメチルメルカプタン $\left(\mathrm{CH}_{3} \mathrm{SH}\right)$, アリルメルカプタンおよびジアリルジスルフィドよは別 に，時間の経過とともにアリルメチルスルフィド（AMS） が検出されることが，明らかにされている゙。 AMSは，ア リル基とメチル基を有するモノスルフィドであり，生体内 での代謝により生成されると推定されている2!.

代表的な口臭成分である $\mathrm{CH}_{3} \mathrm{SH}$ については，消臭に関 する様々なアプローチがなされておりここれまでにクロロ フィル誘導体 ${ }^{3)}$ をはじめ, 緑茶中), ラズベリ一葉5), 延命 草 ${ }^{6)}$, 力カオ八スク などの植物抽出物に消臭効果が確認

テ336-8601 埼玉県さいたま㠴南区沼影 3-1-1

$s$ 連絡先 (Corresponding author)
されている。これらに含まれる消臭活性成分としてはポリ フェノール化合物 ${ }^{4) 577)}$, ジテルペン化合物(6)などであるが, その消臭機構はこれらの反応性部位への $\mathrm{CH}_{3} \mathrm{SH}$ の付加反 応と考えられている.

一方，ニンニクの代謝臭と考えられる AMS は強い臭気 を有する硫黄化合物であるが，チオール基の上うな反応性 の高い部位がないことから，化学的な消臭が難しいと考え られ，消臭に関するアプローチもなされていない．

そこで, AMS 消臭効果を有する天然物の探索を目的と してスクリーニングを行った結果, 数種の植物抽出物に消 臭効果を確認した。本報では探索結果と，その中で特に消 臭活性の高加た甜茶 (Rubus suavissimus S. LEE) 水抽 出物（RSW）の消臭効果について検討した結果を報告す る.

\section{1. 実験材料及び実験方法}

(1) 試 薬

鉄クロロフィリンナトリウムは夕マ生化学(株) 製, アリ ルメチルスルフィド (AMS) および没食子酸は東京化成工 業(株) 製を使用した。 ポリクラール AT は五協産業(株) より入手した。

(2) 供試植物

以下の乾燥植物を入手した。甜茶 (Rubus suavissimus) の葉は, 日本緑茶センターから購入した. ラズベリー(Rubus idaeus) の葉，ブラックベリー（Rubus fruticosus）の葉, ユーカリ（Eucalyptus globulus）の葉, ローズマリー(Rosmarinus officinalis) の葉は, カリス成城から購入した。 ヤマモモ（Myrica rubra）の樹皮は, ウチ多和漢薬から購 入した。 緑茶 (Camellia sinensis var. sinensis) は, 都内 小売店にて購入した.

(3) 植物抽出物の調製方法

乾燥植物の粉末 $20 \mathrm{~g}$ に脱イオン水 $400 \mathrm{ml}$ を加え, $80^{\circ} \mathrm{C}$ で 3 時間還流抽出を行った。抽出液を濾取し, 減圧下濃縮 後, 凍結乾燥することにより各抽出物を得た。

(4) 消臭活性の測定

i ） ガスクロマトグラフィー $(\mathrm{GC})$ 測定条件 : GC 測定 は以下の条件で行った。

GC 装置は Hewlett-Packard 社製 HP5890series II，検 出器には, 炎光光度検出器 (FPD) を用い, 硫黄検出モ一 ドにより測定した。カラムには Hewlett-Packard 社製 HP-5（内径 $0.53 \mathrm{~mm}$, 長さ $30 \mathrm{~m}$, 膜厚 $2.65 \mu \mathrm{m}$ ）を用い, キャリアガスには He を使用した。 カラムへッド圧を 12 psi とし, 注入口温度を $200^{\circ} \mathrm{C}$, 検出器温度を $200^{\circ} \mathrm{C}$ に設定 した.オーブン温度を $50^{\circ} \mathrm{C}$ で 2.5 分保持した後, $30^{\circ} \mathrm{C} / \mathrm{min}$ で $125^{\circ} \mathrm{C}$ まで昇温した。

ii） AMS 溶液の調製：500 ppm AMS エタノール溶液 を調製し, 用時に水で希釈し, 水冷しながら試験に供した。

iii） AMS に対する消臭活性測定：内容量 $30 \mathrm{ml}$ のバイ アル瓶中で試料を $0.2 \mathrm{M}$ リン酸緩衝液（pH 7.5） $1 \mathrm{ml}$ に溶 
解した後 (コントロールは緩衝液のみ), 1 ppm AMS 溶液 $0.25 \mathrm{ml}$ を添加し, 直ちにゴム栓をして混合した。これを $37^{\circ} \mathrm{C}$ で， 2 時間振とうした後，ヘッドスペースガス $100 \mu \mathrm{l}$ をGC-FPDに注入し, AMSのピークの高さを測定した. 結果は予妰成した AMS の検量線により AMS 量を算出 し，下記計算式により消臭率で示した。

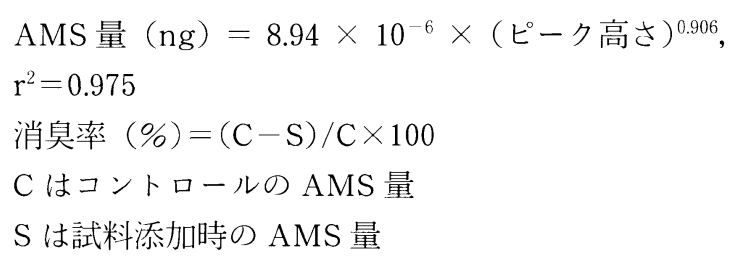

（5）甜茶抽出物 (RSW) 中のポリフェノール成分の部分 的除去処理

$\mathrm{RSW} 1 \mathrm{~g}$ を水 $50 \mathrm{ml}$ に溶解し,これにポリクラール AT (抽出物に対し重量比 $1: 0.2,1: 0.5,1: 1,1: 2$ ) をそれ ぞれ加え, 1 時間攪拌後濾過した。残渣を水 $25 \mathrm{ml}$ で 2 回 洗浄後, 濾液および洗浄液を合わせ, 濃縮し, さらに涷結 乾燥した，以上の操作により, 各種ポリフェノール濃度に 調製したRSW を得た。なお，各抽出物の全ポリフェノー ル量はGallic acid を標準物質として, Folin-Ciocalteu 法帛により測定した。

（6）甜茶抽出物（RSW）の精製

RSW $15 \mathrm{~g}$ は, Diaion HP20 (三菱化学(株) 製) による カラムクロマトグラフィー (内径 $40 \mathrm{~mm}$, 長さ $180 \mathrm{~mm}$ ) により分画した。溶出溶媒は水とエ夕ノールの混合液を用 い，エタノール濃度は０～ $80 \%$ とし，20\%毎の段階的勾配 でそれぞれ $300 \mathrm{ml}$ で溶出を行った。得られた 5 画分 （RSW-1〜5）は減圧濃縮後, 凍結乾燥により粉末化した。 RSW-2 $2 \mathrm{~g}$ を, Sephadex LH-20（ファルマシア(株）製） によるカラムクロマトグラフィー $(20 \mathrm{~mm}$ i.d. $\times 200 \mathrm{~mm})$ により分画した，溶出溶媒は水とメ夕ノールの混合液を用 い,メ夕ノール濃度は $0,10,30,50,100 \%$ とし, それぞれ $100 \mathrm{ml}$ で溶出させ, 最後に $50 \%$ アセトン $200 \mathrm{ml}$ で溶出さ せた。得られた 6 画分（RSW-21〜RSW-26）は減圧濃縮 後, 凍結乾燥により粉末化した。

(7) 消臭反応後の試料液の GC 分析

内容量 $30 \mathrm{ml}$ のバイアル瓶中で RSW-24 $5 \mathrm{mg}$ を $0.2 \mathrm{M}$ リン酸緩衝液（pH 7.5）1 ml で溶解後, 50 ppm AMS 溶液 $0.25 \mathrm{ml}$ を添加し $37^{\circ} \mathrm{C}$ で, 2 時間反応させた. 反応により得 られた試料液 $1 \mu \mathrm{l}$ を GC-FPD に注入し消臭活性測定の場 合と同じ条件で，成分分析を行った。

アリルメチルスルホキシド (AMSO) 標品は, 容量 $30 \mathrm{ml}$ のナス型フラスコ中で AMS $5.67 \mathrm{mmol}(500 \mathrm{mg})$ に対し て $567 \mathrm{mM}$ 過酸化水素 $10 \mathrm{ml}$ を加え, 室温下で 2 時間覺拌 し調製した.GC-FPDにより酸化反応の終了を確認し, GC-MS 分析により AMSO であることを確認した.

(8) 消臭反応に及ぼす酸素の影響
内容量 $30 \mathrm{ml}$ のバイアル瓶中で試料 RSW- $243 \mathrm{mg}$ を $0.2 \mathrm{M}$ リン酸緩衝液 ( $\mathrm{pH} 7.5) 1 \mathrm{ml}$ で溶解後, バイアル瓶内 のヘッドスペースガスを窒素置換し，テフロン製の蓋とア ルミシールで密封した。 $1.25 \mathrm{ppm}$ AMS $0.2 \mathrm{ml}$ をシリンジ で添加後, $37^{\circ} \mathrm{C}$ で経時的にヘッドスペースガス中の AMS に対して GC-FPD 分析を行った. 2 時間後の測定後, 酸素 または窒素ガス $8 \mathrm{ml}$ をシリンジで注入し，引き続きへッ ドスペースガス中の AMS を経時的に測定した。なおリ ン酸紱衝液は，窒素ガスでバブリングしたものを用いた。 悪臭源である $1.25 \mathrm{ppm}$ AMS 溶液は, $500 \mathrm{ppm}$ AMS 溶液 （エタノール）を窒素ガスでバブリングした水により希釈 し調製した。

\section{2. 実験結果及び考察}

(1) 各種植物抽出物の消臭活性

ニンニクを撕取した後に発生するAMSに対して消臭効 果を有する植物抽出物の探索を行った. 350 種の抽出物に ついて検討し, その中で消臭効果の認められた 5 種類の植 物抽出物の収率㧍よび各試料 $(10 \mathrm{mg})$ の消臭率を表 1 に 示した.

今回評価した植物抽出物の中で最も高い消臭活性を示し たのは甜茶抽出物（RSW）であり， $78 \%$ の消臭率示し た. 続いてヤマモモ樹皮, ユーカリ葉およびラズベリ一葉 の抽出物は $50 \%$ 以上の消臭率を示した。 口臭の主要成分 である $\mathrm{CH}_{3} \mathrm{SH}$ に対して消臭効果が報告されている緑茶》， ローズマリー葉9) および鉄クロロフィリンナトリウムも同 様に評価したが, 緑茶抽出物が $21 \%$ の消臭率を示したほ かは $10 \%$ 以下の消臭率であった。 今回最も消臭効果が優 れていた甜茶について, 活性成分および消臭機構の検討を 行った.

（2）甜茶抽出物（RSW）の消臭活性成分の検討

$\mathrm{CH}_{3} \mathrm{SH}$ に対する消臭成分として各種のポリフェノール 化合物が知られている。甜茶の成分としても種々のポリ フェノール化合物が報告されていることから ${ }^{10)}$, ポリフェ ノール成分に着目し, AMS 消臭活性成分の検討を行った. まず， RSWのポリクラール ATによる部分的ポリフェ ノール成分除去処理を行った。ポリクラール ATはポリ

表 1 各種植物抽出物の収率と消臭効果

\begin{tabular}{|c|c|c|}
\hline 試 料 & 収率 & 消臭率* $(\%)$ \\
\hline 甜茶 & $23 \%$ & $78 \%$ \\
\hline ヤマモモ樹皮 & $17 \%$ & $61 \%$ \\
\hline ユーカリ葉 & $18 \%$ & $58 \%$ \\
\hline ラズベリー葉 & $17 \%$ & $55 \%$ \\
\hline ブラックベリ一葉 & $17 \%$ & $43 \%$ \\
\hline 鉄クロロフィリンナトリウム & - & $3 \%$ \\
\hline 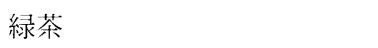 & $33 \%$ & $21 \%$ \\
\hline ローズマリー葉 & $17 \%$ & $5 \%$ \\
\hline
\end{tabular}

*消臭率は試料量 $10 \mathrm{mg}$ で測定. 
フェノール成分を特異的に吸着する高分子ポリマーであ り, 宇井らはラズベリー葉抽出物中のポリフェノール類の 除去に利用している5). 各比率でのポリクラール AT の処 理により, RSW 中のポリフェノール含有率を $5.8 \sim 27.4 \%$ の範囲で調製することができた。これらの処理物のポリ フェノール含量之消臭活性との関係を図 1 に示した. 各処 理物のポリフェノール組成は明らかではないが，ポリフェ ノール含量と消臭活性との間には明らかな正の相関が見ら れることから, 消臭活性発現にポリフェノール成分が関与 していることが示された。

次に RSW の活性成分についてポリフェノール成分を指 標に精製を行い，消臭活性を測定した，RSWをDiaion HP20 を用いたカラムクロマトグラフィーにより分画を 行った. RSW を樹脂に吸着後, 水一エタノール系で溶出さ

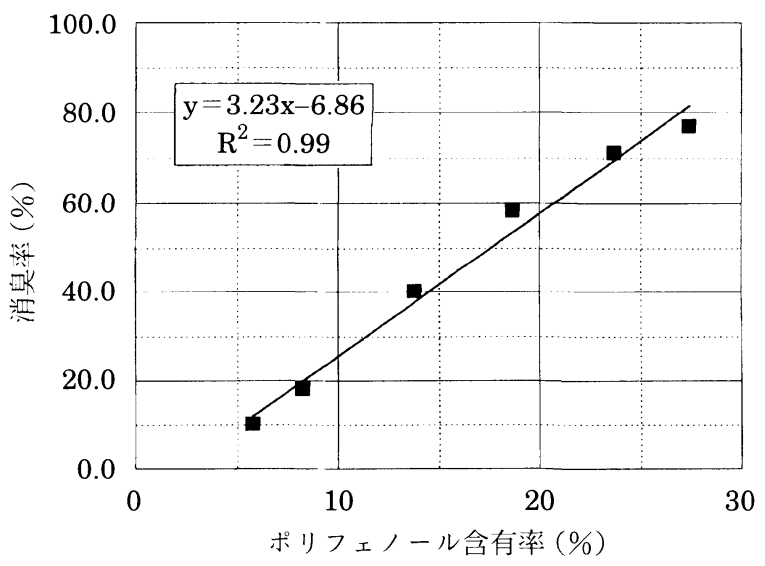

図 1 ポリクラール AT 処理甜茶抽出物の消臭効果と ポリフェノール含量の関係

ロ，ポリクラール AT 処理した甜茶抽出物
せ，5画分（RSW-1〜5）に分画した. 各画分の収率，ポリ フェノール含量, 消臭活性（試料量 $10 \mathrm{mg}$ ) を表 2 に示し た。最も収率の高い画分はRSW-1 であったが，消臭活性 は低く，ポリフェノール含量も低いものであった。最も活 性の高い画分である RSW-2 は試料量 $10 \mathrm{mg}$ で $92 \%$ の消 臭率を示した，消臭活性は $80 \%$ 以上で飽和傾向を示し，添 加量と消臭活性の相関が低くなることから試料量 $3 \mathrm{mg}$ に おける消臭活性評価を行なったところ，3 mgにおいても 80\%の消臭活性が確認された。 そこで，さらに Sephadex LH-20 によるカラムクロマトグラフィーにより RSW-2 を 分画した. 10\%〜 100\%メタノール溶出部（RSW-22～25） のそれぞれの画分に打けるポリフェノール含有率は $58.3 \%$ から $75.1 \%$ ，消臭率も $74 \%$ から $86 \%$ となり，消臭活性を 有するポリフェノール成分は各画分に分散しており，特異 的に高い消臭活性を有する画分は見られなかった。従っ て, 甜茶に含まれる有効成分は, 幅広い物理的性質を有す るポリフェノール化合物の混合体である上考えられた。 各 画分の消臭活性をみると $50 \%$ メ ノール溶出部（RSW24）で，消臭率は $86 \%$ と最大になり，ポリフェノール含有 率は $64.0 \%$ であった. RSW-25 および $50 \%$ アセトン溶出 部（RSW-26）ではポリフェノール含量はRSW-24を上 回ったが，消臭活性は減少した。従って，ポリフェノール の極性や分子量などその性質の違いや阻害成分による消臭 活性への影響屯示唆された。しかし, 前述のポリクラール ATでのポリフェノール除去実験の結果や RSW - 22〜26 のポリフェノール高含有画分はいずれも消臭活性を有して いることから，消臭活性発現に対してはポリフェノールの 性質よりあ量が重要と考えられた。 中原, 平井らは, 甜茶 抽出物のポリフェノール成分はエラジタンニン類であり,

表 2 甜茶抽出物より得られた分画物のポリフェノール含量と消臭効果

\begin{tabular}{|c|c|c|c|c|c|}
\hline \multirow[t]{2}{*}{ 試料 } & \multirow[t]{2}{*}{ 精製方法 } & \multirow[t]{2}{*}{ 収率 * } & \multirow[t]{2}{*}{$\mathrm{PP}^{* *}$ 含有率 } & \multicolumn{2}{|c|}{ 消臭率 } \\
\hline & & & & $10 \mathrm{mg}$ & $3 \mathrm{mg}$ \\
\hline \multirow[t]{2}{*}{ 水抽出物 } & & & $27.0 \%$ & $74 \%$ & \\
\hline & Diaion HP20 & & & & \\
\hline RSW-1 & 水 & $41.6 \%$ & $9.4 \%$ & $30 \%$ & \\
\hline RSW-2 & $20 \%$ エタノール & $17.1 \%$ & $60.9 \%$ & $92 \%$ & $80 \%$ \\
\hline RSW-3 & $40 \%$ エタノール & $16.9 \%$ & $55.4 \%$ & $82 \%$ & \\
\hline RSW-4 & $60 \%$ エタノール & $14.6 \%$ & $15.9 \%$ & $11 \%$ & \\
\hline \multirow[t]{2}{*}{ RSW-5 } & $80 \%$ エタノール & $6.3 \%$ & $3.4 \%$ & $4 \%$ & \\
\hline & Sephadex LH-20 & & & & \\
\hline RSW-21 & 水 & $35.0 \%$ & $34.2 \%$ & & $39 \%$ \\
\hline RSW-22 & $10 \% \times$ タノール & $8.0 \%$ & $58.3 \%$ & & $74 \%$ \\
\hline RSW-23 & 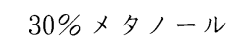 & $5.5 \%$ & $61.4 \%$ & & $78 \%$ \\
\hline RSW-24 & $50 \%$ メタノール & $8.5 \%$ & $64.0 \%$ & & $86 \%$ \\
\hline RSW-25 & $100 \%$ メタノール & $9.5 \%$ & $75.1 \%$ & & $77 \%$ \\
\hline RSW-26 & $50 \%$ アセンン & $27.0 \%$ & $75.3 \%$ & & $60 \%$ \\
\hline
\end{tabular}

* RSW-21 から RSW-26 までの収率は, RSW-2 量を元とした值.

**ポリフェノール. 
(1) RSW-24 画分無添加系

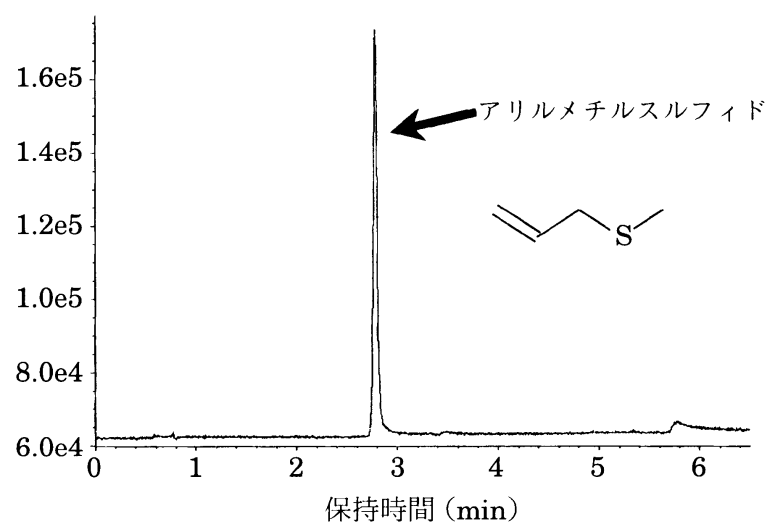

(2) RSW-24 画分添加系

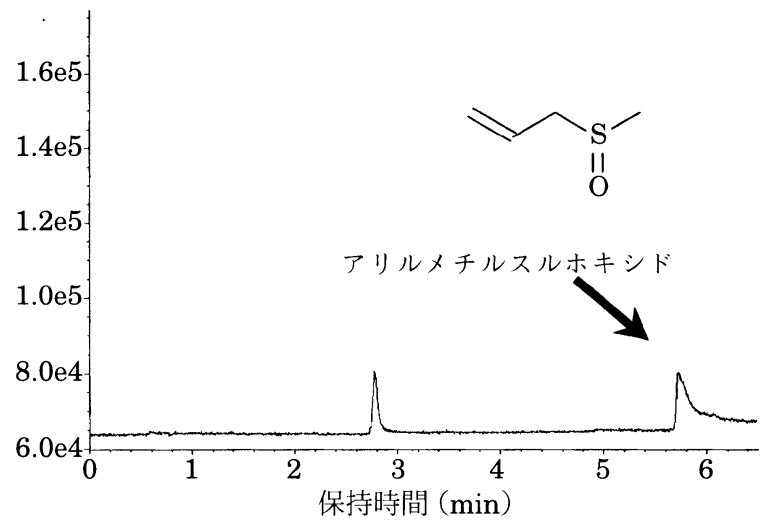

図 2 アリルメチルスルフィドと甜茶分画物反応後の 硫黄化合物の分析

そのヒスタミン遊離抑制成分としてエラジタンニンのポリ マーを報告している ${ }^{11) 12)}$. 今回の AMS に対する消臭活性 あこれらのエラジタンニン類が関与している可能性が高い と考えられた. 今後ポリフェノール以外の消臭成分の存在 あ含め詳細な成分の検討を行なう予定である.

(3) 消臭反応後の試料液の GC 分析

甜茶ポリフェノールの消臭反応機構を推測する為に, SW-24 と AMS の反応液を GC-FPD を用いて分析を行っ た。図 2 にチャートを示した，RSW-24を加えることで AMSの減少が認められ，アリルメチルスルホキシド (AMSO) の増加が確認された。このことから, 甜茶ポリ フェノールの AMS 消臭機構の主体は, 硫黄原子の酸化反 応であることが推測された。

\section{(4) 消臭反応に及ぼす酸素の影響}

甜茶ポリフェノールの AMS 消臭反応が AMSO のの酸 化反応であると推測されたことから，消臭反応における酸 素の影響について検討を行った。結果を図 3 に示した。試 薬および反応容器内を窒素ガス置換した場合においては, RSW-24を添加して 2 時間反応を行っても, AMS 量には ほとんど減少は認められなかった。 その後, 容器内には酸

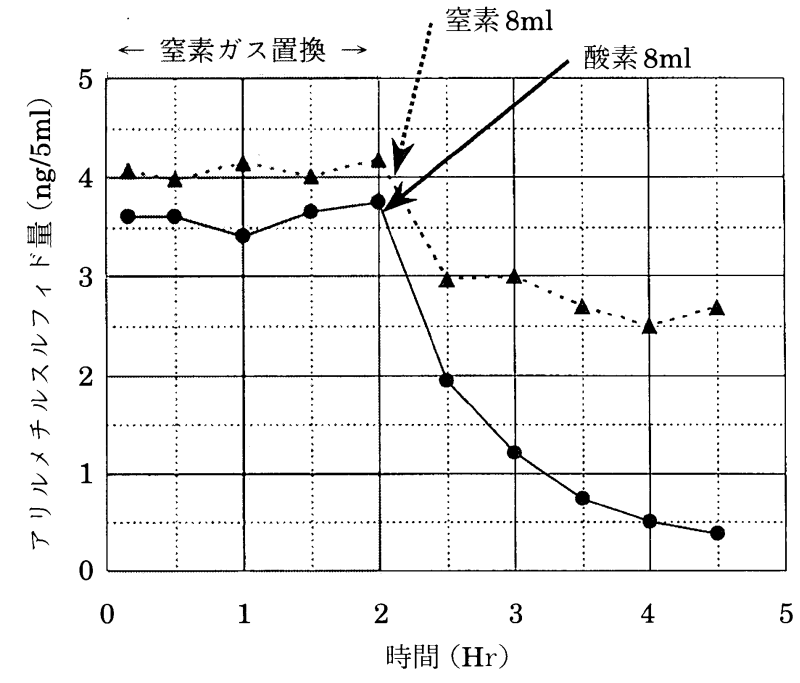

図 3 甜茶の消臭反応に及ぼす酸素の影響

$\boldsymbol{\Delta}, 2$ 時間後から窒素 $8 \mathrm{ml}$ を注入

○, 2 時間後から酸素 $8 \mathrm{ml}$ を注入

素むしくは窒素 $8 \mathrm{ml}$ を注入し, 経時的に AMS 量を測定 した。 その結果，酸素を注入した場合にのみ消臭反応が進 行し，窒素においては希釈による一時的な AMS の減少が 認められる他は，消臭反応に由来する AMS の減少は確認 できなかった。 また，RSW-24を加えずに，酸素を注入し た場合においても消臭反応は認められなかった。従って, 甜茶の消臭反応には，ポリフェノール化合物之酸素の両方 が必要であることが確認された。

以上の結果から, 甜茶ポリフェノール類は酸素の存在下 で AMS の硫黄原子を酸化し, 不揮発性の AMSO に変化 させることにより消臭効果を発現するあのと考えられた。 甜茶は, 抗アレルギー食品素材として広く使用されている が, 本研究結果は, ニンニク代謝臭に対する甜茶の応用之 いう新たな可能性を示唆するものであった。

\section{3. 要 約}

アリルメチルスルフィド (AMS) に対して消臭効果を有 する植物抽出物の探索を目的として, 消臭活性スクリーニ ングを行い，以下の知見を得た。

（1）各種植物抽出物を用いて AMS に対する消臭活性評 価を行った結果, 甜茶, ヤマモモ樹皮, ユーカリ葉の水抽 出物は高い消臭活性を示した.

(2) 消臭活性の最も高い甜茶水抽出物 (RSW) に対して 脱ポリフェノール処理を行い, 処理物中のポリフェノール 含量と消臭活性を調べた結果，両者の間には高い相関性が 認められた。 また, RSWの分画により得られたポリフェ ノール高含有画分において, 高い消臭活性が認められたこ とから, 甜茶の消臭効果にはポリフェノール成分が関与し ていることが明らかとなった。

(3) ガスクロマトグラフを用いて活性画分 RSW-24 と AMS との消臭反応後の生成物を分析したところ，アリル 
メチルスルホキシド（AMSO）が検出された.

（4）嫌気条件下で甜茶分画物による AMS 消臭試験を 行った結果, AMS 消臭反応には酸素が必要であることが 明らかとなったことから, 甜茶の消臭反応としてポリフェ ノール成分存在下で AMS が酸化され, AMSO へ変換す る反応機構が推定された。

\section{文献}

1) Taucher, J., Hansel, A., Jordan, A. and Lindinger, W., Analysis of Compounds in Human Breath after Ingestion of Garlic Using Proton-Transfer-Reaction Mass Spectrometry. J. Agric. Food Chem., 44, 3778-3782 (1996).

2) Block, E., Garlic as a Functional Food: A Status Report. ACS. Symp. Ser., 702, 125-143 (1998).

3）角田正健, 佐藤春海, 大串 勉, 銅クロロフィリンナトリウ 么の口臭抑制効果一唾液による実験的研究，日本㐘周病学 会会誌, 23，490-498（1981）.

4）宇井美樹, 安田英之, 柴田柾樹, 丸山 孝, 堀田 博, 原 利男, 安田 環, 茶カテキン類の口臭抑制効果とチューイ ンガムへの応用, 食工誌, 38, 1098-1102（1991）.
5）安田英之, 宇井美樹, バラ科植物抽出物のメチルメルカプ タンに対する消臭効果, 農化， 66， 1475-1479（1992）.

6) Yasuda, H., Shimizu, K. and Osawa, K., Deodorizing Activity of Diterpenes from the Leaves of Rabdosia trichocarpa and of Several $\alpha$, $\beta$-Unsaturated Carbonyl Compounds against Methanethiol. Biosci. Biotech. Biochem., 60, 88-91 (1996).

7）清水和正, 前田裕一, 大澤謙二, 志村 進, 角田正健, 力力 オポリフェノールのメチルメルカプタンに対する消臭効 果，食科工，48，238-245（2001）.

8) Scalbert, A., Monties, B. and Janin, G., Tannins in Wood : Comparison of Different Estimation Methods. J. Agric. Food Chem., 37, 1324-1329 (1989).

9）常田文彦, 石川正夫, 渋谷耕司, 植物抽出物のメチルメルカ プタンに対する消臭作用，農化， 58，585-589（1984）.

10) Sugimoto, N., Kikuchi, H., Yamazaki, T. and Maitani, T., Polyphenolic Constituents from the Leaves of Rubus suavissimus. Natural Medicines, 55, 219 (2001).

11）中原光一, 甜茶の機能研究の現状と展望, 月刊フードケミ カル, 9, 44-48 (1995).

12）平井孝一, 甜茶抽出物の抗アレルギー作用之食品への利用, 32 (2), 22-24 (1997).

(平成 15 年 8 月 6 日受付，平成 16 年 1 月 27 日受理) 